University on May 12; on May 13, Beverly T. Moss represented ALA at the inauguration of William Lincoln Giles as president of Mississippi State University. At Chico State College, Chico, Calif., on May 20, Gordon Martin attended as ALA representative the inauguration of Robert Eugene Hill as president of the College; and at State University of New York at Buffalo, on May 29, John R. Russell, the inauguration of Martin Mayerson as president of the university.

\section{ACRL EXHIBIT BOOTH}

ACRL will again provide an exhibit booth (No. 243) at the ALA conference in San Francisco. The booth will serve as a center of information about ACRL activities, including publications and reprints of interest to academic and research librarians. Inquiries for information can be answered by academic librarians who are staffing the booth, or left for answering by the ACRL executive secretary after he returns to the ALA headquarters in July.

The ACRL booth is being manned by academic librarians of the San Francisco Bay area under the supervision of Juliet B. Clark, acting university librarian, University of San Francisco, and chairman of the ACRL Committee on Local Arrangements.

Special emphasis is being provided in two areas of ACRL activity:

1. The ACRL Audio-Visual Committee will provide information relative to the purpose and activities of the committee, as well as books, articles and other items on the establishment, use, promotion and evaluation of audio-visual materials and services, primarily in academic libraries. Committee members and consultants will be present to answer questions and offer assistance to delegates interested in $\mathrm{A}-\mathrm{V}$ problems and programs.

2. The Junior College Libraries Section of ACRL will provide copies of bibliographies, surveys, and other information of interest to junior college librarians for assistance in development of effective library programs. Sample copies of handbooks will be available for browsing. Members of the Section also plan to assist in the staffing of the booth, to act as consultants.

The booth, located in Brooks Hall, will be open from Sunday, June 25, through Thursday, June 29, during the regular exhibit hours.

ACRL Membership: April 30, 1967

10,978

April 30, 1966

9,669

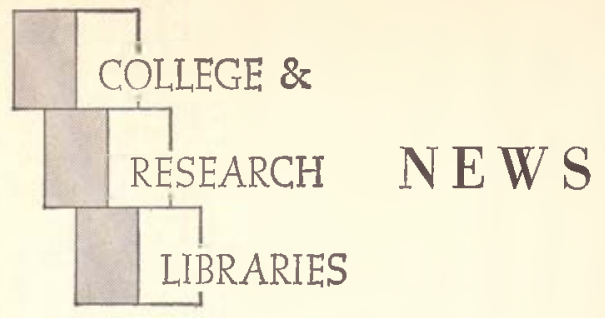

ACRL News Issue of College \& Research Libraries

Editor, David Kaser, Joint University Libraries, Nashville, Tenn. 37203.

Publications Officer, Mary Falvey, 50 E. Huron St., Chicago 60611.

ACRL Executive Secretary, George M. Bailey.

ACRL Officers, 1966/67: President, Ralph E. McCoy College Libraries Section Chairman, Lee Sutton; Junio College Libraries Section, Harriett Genung; Rare Books Section, William H. Runge; Subject Specialists Section, Mary E. Schell; Agriculture and Biological Sciences Subsection Chairman, Roy L. Kidman; Art Subsection, Mrs. Kathryn Blackwell; Law and Political Science Subsection, Jane Wilson; Slavic and East European Subsection, Bohdan S. Wynar; University Libraries Section Chairman, John M. Dawson.

Editorial Board: JoHn M. Dawson, University of Delaware; Gustave A. Harrer, Boston University; SaMvel RothsteIn, University of British Columbia; James E. Skipper, Princeton University; Norman E. Tanis, Kansas State College of Pittsburg; Maurice F. Tauber, Columbia University; EILeEN Thonnton, Oberlin College.

News from the Field, Personnel profiles and notes, classified advertising, official matter of ACRL, and other material of a timely nature is published in the News issues of College \& Research Libraries.

Inclusion of an article or advertisement in CRL does not constitute official endorsement by ACRL or ALA Production and Advertising and Circulation office: 50 E. Huron St., Chicago, IIl. 60611. Change of address and orders for subscriptions should be addressed to College \& Research Libraries, for receipt at the above address, at least two months before the publication date of the effective issue.

Subscription to $C R L$ is included in membership dues to $A C R L$ of $\$ 6$ or more; other subscriptions to $C R L$ are $\$ 10$ per year. Neither subscriptions nor memberships include miscellaneous unscheduled supplements, which are available by purchase only. Retroactive subscriptions are not accepted. Single journal copies are available at $\$ 1.50$ each and News issues at $\$ 1.00$ each from ALA Publishing Department.

Indexed in Library Literature. Abstracted in Library Science Abstracts. Book reviews indexed in Book Re view Index.

College \& Research Libraries, is the official journal of the Association of College and Research Libraries, division of the American Library Association; and is published seventeen times per year-bi-monthly as a technical journal with 11 monthly News issues, combining July-August-at 1201-05 Bluff St., Fulton, Mo. 65251 .

Second-class postage paid at Fulton, Mo. and at additional mailing offices. 